\title{
Sr-Nd isotope systematics in 14-28 Ma low-temperature altered mid-ocean ridge basalt from the Australian Antarctic Discordance, Ocean Drilling Program Leg 187
}

\section{Sylwia Krolikowska-Ciaglo \\ Leibniz-Institut für Meereswissenschaften an der Universität Kiel, IFM-GEOMAR, Wischhofstrasse 1-3, 24148 Kiel, Germany}

Now at Instytut Geologii, Uniwersytet im. Adama Mickiewicza, ul. Maków Polnych 16, 61-606 Poznań, Poland (skrolikowska@ifm-geomar.de)

\section{Folkmar Hauff and Kaj Hoernle}

Leibniz-Institut für Meereswissenschaften an der Universität Kiel, IFM-GEOMAR, Wischhofstrasse 1-3, 24148 Kiel, Germany (fhauff@ifm-geomar.de; khoernle@ifm-geomar.de)

[1] The effects of low-temperature alteration on the $\mathrm{Rb}-\mathrm{Sr}$ and $\mathrm{Sm}-\mathrm{Nd}$ isotope systems were investigated in 14-28 Ma mid-ocean ridge basalts recovered during Ocean Drilling Program (ODP) Leg 187 from the Australian Antarctic Discordance through comparison of pristine glass and associated variably altered basalts. Both $\mathrm{Nd}$ and $\mathrm{Sm}$ are immobile during low-temperature alteration, and ${ }^{143} \mathrm{Nd} /{ }^{144} \mathrm{Nd}$ displays mantle values even in heavily altered samples. In contrast, ${ }^{87} \mathrm{Sr} /{ }^{86} \mathrm{Sr}$ and $\mathrm{Rb}$ concentrations increase during seawater-rock interaction, which is especially apparent in single samples with macroscopically zoned alteration domains. The increase in ${ }^{87} \mathrm{Sr} /{ }^{86} \mathrm{Sr}$ roughly correlates with the visible degree of alteration, indicating a higher seawater/rock ratio in the more altered samples. Sr concentrations, however, do not systematically increase with increasing degree of alteration, most likely reflecting exchange of $\mathrm{Sr}$ in smectite interlayer sites. The degree of alteration in the uppermost oceanic crust of the Australian Antarctic Discordance is independent of crustal age. A comparison with literature data for young and old altered oceanic crust suggests that most low-temperature alteration occurs within a few million years after formation of the oceanic crust, probably reflecting greater fluid flux through the crust during its early history as a result of higher permeability and increased fluid circulation near the ridge.

Components: 8624 words, 7 figures, 4 tables.

Keywords: low-temperature alteration; basalts composition; oceanic crust; $\mathrm{Rb}-\mathrm{Sr}$ and $\mathrm{Sm}-\mathrm{Nd}$ isotope systems.

Index Terms: 1040 Geochemistry: Radiogenic isotope geochemistry; 1065 Geochemistry: Major and trace element geochemistry; 1039 Geochemistry: Alteration and weathering processes (3617).

Received 13 July 2004; Revised 28 September 2004; Accepted 11 November 2004; Published 14 January 2005.

Krolikowska-Ciaglo, S., F. Hauff, and K. Hoernle (2005), Sr-Nd isotope systematics in 14-28 Ma low-temperature altered mid-ocean ridge basalt from the Australian Antarctic Discordance, Ocean Drilling Program Leg 187, Geochem. Geophys. Geosyst., 6, Q01001, doi:10.1029/2004GC000802.

\section{Introduction}

[2] Ocean Drilling Program (ODP) Leg 187 [Christie et al., 2001] mapped the paleoboundary between the Indian and Pacific mantle domains in a 14-28 Ma crustal profile immediately north of the Australian Antarctic Discordance (AAD), providing valuable constraints for the reconstruction and 
evolution of this important mantle boundary [Kempton et al., 2002]. The availability of variably altered basalt together with fresh basalt and fresh glass from a large number of drill sites that cover a substantial section of relatively young crust provide an excellent opportunity to investigate the temporal and the compositional effects of alteration in the uppermost oceanic crust through time.

[3] While high-temperature alteration of oceanic crust primarily takes place during and shortly after the formation of oceanic crust at spreading centers, low-temperature alteration $\left(<50^{\circ} \mathrm{C}\right)$ may last over extended periods, affecting both the chemical composition of seawater and the crust. It is not known exactly how long the seawater-basalt interaction takes place. Numerous studies based on physical properties of basalts suggest that low-temperature alteration of the oceanic crust is progressive and age-dependent [e.g., Johnson and Semyan, 1994; Zhou et al., 2001]. On the other hand, some mineralogical [Talbi and Honnorez, 2003] and isotopic [Hauff et al., 2003] investigations imply that low-temperature alteration primarily occurs during the first few million years after crust formation and that only precipitation of carbonates has a major effect on the composition of the crust throughout its history on the seafloor [Alt and Teagle, 1999].

[4] Alteration studies of in situ ocean crust have thus far mainly focused on DSDP/ODP Sites 417/ 418 [Staudigel et al., 1995; 1996], 735B [Bach et al., 2001], 504B [Alt et al., 1996a, 1996b; Bach et al., 2003], Sites 801 and 1149 [Kelley et al., 2003; Hauff et al., 2003] and crustal xenoliths associated with intraplate volcanism [Hoernle, 1998; Schmincke et al., 1998]. Previous studies of the alteration of oceanic crust have concentrated either on very young $(<15 \mathrm{Ma})$ or old $(>100 \mathrm{Ma})$ oceanic crust and crust of intermediate age (15-100 Ma) has been less extensive investigated. Here we report $\mathrm{Rb}, \mathrm{Sr}, \mathrm{Sm}$, and $\mathrm{Nd}$ concentrations and $\mathrm{Sr}-\mathrm{Nd}$ isotopic compositions of pristine glass, fresh and variably altered basalts from 11 Sites drilled into 14-28 Ma ocean crust during ODP Leg 187. The high fluid mobility of $\mathrm{Sr}$ and the relatively high $\mathrm{Sr}$ concentrations in seawater $(8 \mathrm{ppm})$ in conjunction with large differences in ${ }^{87} \mathrm{Sr} /{ }^{86} \mathrm{Sr}$ composition between normal mid-ocean ridge basalts $(\sim 0.7026)$ and seawater $(0.70906)$ have been widely used to trace seawater-crust interactions [e.g., Barrett and Friedrichsen, 1982; Kawahata et al., 1987; Staudigel et al., 1981, 1995, 1996; Alt et al., 1996a; Hoernle,



Figure 1. (a) Regional map of the eastern Indian and western Pacific seafloor showing the working area of ODP Leg 187 north of the Southeast Indian Ridge (modified from Pedersen et al. [2004]. (b) Map showing locations of ODP Leg 187 drill sites relative to 1 m.y. seafloor isochrones (gray lines). Red and yellow stars represent sites with Indian and Pacific mantle domain characteristics respectively (modified from Christie et al. [2001]). 
1998]. In contrast, Nd remains immobile during low-temperature alteration, thus seawater $\left({ }^{143} \mathrm{Nd} /{ }^{144} \mathrm{Nd}=0.51223\right)$ has no known effect on $\mathrm{Nd}$ concentrations and ${ }^{143} \mathrm{Nd} /{ }^{144} \mathrm{Nd}$ ratios in altered oceanic crust $(\sim 0.51300)$ [e.g., Staudigel et al., 1995; Hoernle, 1998; Hauff et al., 2003]. Therefore $\mathrm{Nd}$ serves as an excellent reference element to chart the source composition of the oceanic crust.

\section{Geological Setting}

[5] The study area lies within the Australian Antarctic Discordance (AAD) that is located along the Southeast Indian Ridge (SEIR), between $115^{\circ} \mathrm{E}$ and $130^{\circ} \mathrm{E}$ longitudes, at the apex of a westward pointing, V-shaped depth anomaly that extends from southern Australia to Antarctica (Figure 1a). It forms an extensive, $600 \mathrm{~km}$ long and $25 \mathrm{~km}$ wide depression on the seafloor [Marks et al., 1990; Pyle et al., 1992; Christie et al., 1998]. The anomalously deep water depth of the AAD $(4-5 \mathrm{~km})$ is thought to result from relatively thin ocean crust lying above unusually cold mantle [Forsyth et al., 1987; Marks et al., 1990]. The bathymetry of the AAD is unusually chaotic and in part similar to that of slow spreading centers with irregular blocks separated by deep axial valleys and mostly bounded by orthogonal spaced scarps [Christie et al., 1998, 2001]. Within the AAD, Pacific MORB source and Indian MORB source mantle domains intertwine [Klein et al., 1988; Pyle et al., 1992] and are readily identified based on chemical differences such as $\mathrm{Ba} / \mathrm{Zr}$ ratios [Christie et al., 2001] and $\mathrm{Nd}-\mathrm{Hf}-\mathrm{Pb}$ isotope systematics [Kempton et al., 2002].

\section{Samples and Analytical Procedures}

[6] ODP Leg 187 drilled a total of 23 holes at 13 sites (Figure 1) and recovered $137 \mathrm{~m}$ of basaltic core [Christie et al., 2001]. The crustal age of the drill sites is estimated based on their relative position to seafloor magnetic isochrons (Figure 1b) and ranges from $\sim 14 \mathrm{Ma}$ (Site 1159 ) to $\sim 28 \mathrm{Ma}$ (Sites 1154 and 1153). The sediment thickness ranges from $22 \mathrm{~m}$ at Site 1152 to $348 \mathrm{~m}$ at Site 1162, but it is not correlated with crustal age (Table 1). Our study is based on 41 whole rock samples from 11 drill sites. Sites 1152, 1155, 1156, 1161, 1163 and 1164 are located in Indian-type ocean crust and Sites 1154, 1158, 1159 and 1160 are in Pacific-type crust. Both mantle domains appear to be present at Site 1157. Because of poor recovery, it was not 







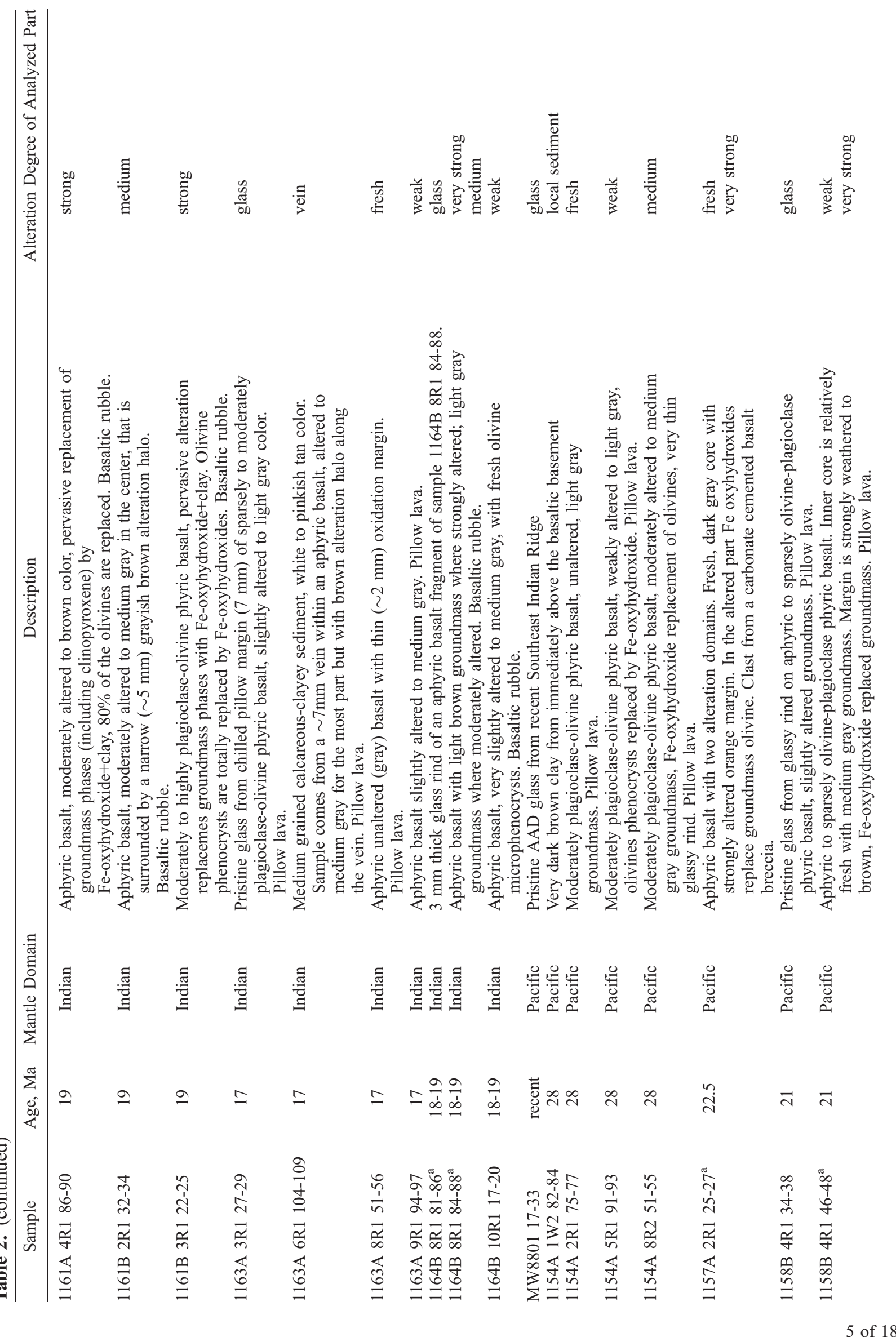




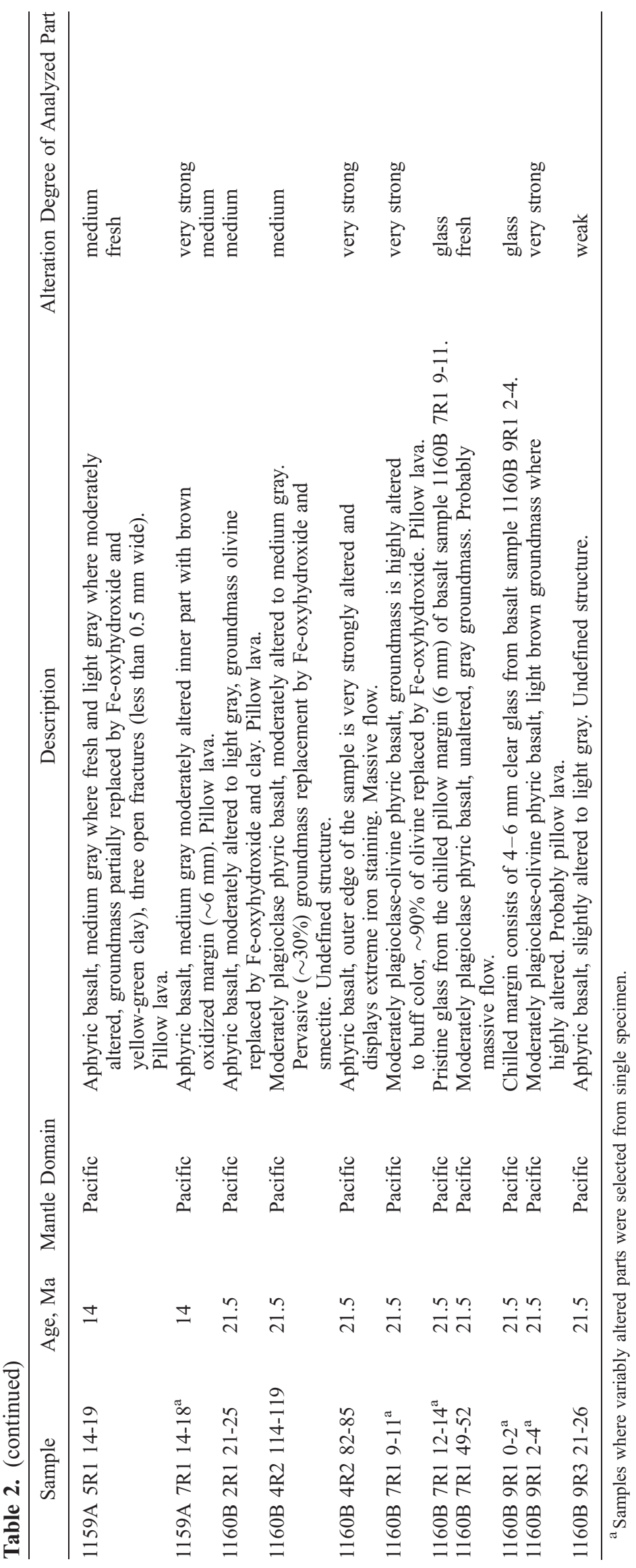


Table 3. Macroscopic Classification Scheme Used to Assign the Degree of Alteration for Samples of This Study

\begin{tabular}{|c|c|}
\hline & Description \\
\hline Fresh & fresh basalt (dark gray to gray) without any secondary phases \\
\hline Weakly altered & $\begin{array}{l}\text { basalts with slight color changes of the groundmass (gray, light gray to medium gray), } \\
\text { unaltered phenocrysts }\end{array}$ \\
\hline Medium altered & $\begin{array}{l}\text { moderate color change of groundmass (medium grey, light brown), groundmass and/or } \\
\text { phenocryst replaced by } 30-40 \% \mathrm{Fe} \text {-oxyhydroxides and smectites }\end{array}$ \\
\hline Strongly altered & $\begin{array}{l}\text { strong color change of groundmass (brownish to orange), phenocryst and groundmass } \\
\text { replaced by } 40-60 \% \mathrm{Fe} \text {-oxyhydroxides and smectites }\end{array}$ \\
\hline Very strongly altered & $\begin{array}{l}\text { complete color change of groundmass (brown to orange brown), phenocrysts completely } \\
\text { replaced by secondary phases (Fe-oxyhydroxide and/or clay) }\end{array}$ \\
\hline Vein material & calcareous sediment \\
\hline
\end{tabular}

always possible to sample fresh glass, fresh basalt and variously altered basalts at each site. Where possible, variably altered parts were preferentially selected from single specimens, and selected pairs are noted in Table 2. From four samples (1157B4R1136-140 and 1164B8R181-86, 84-88 and 1160B 7R1 9-11, 12-14 and 1160B9R10-2, 2-4) fresh glass along with medium to very strongly altered groundmass were obtained. The macroscopically assigned degree of alteration is defined by groundmass color and degree of phenocryst alteration, following the scheme outlined in Table 3. Besides basaltic material, local sediment (1154A1W282-84) and calcareous vein material (from sample 1163A6R1104-109) were also analyzed. In addition three glass samples from the recent SEIR spreading ridge (one from the Pacific (MW880117-33) and two from Indian (MW880127-8 and MW880129-05) mantle domains) were analyzed for $\mathrm{Sr}-\mathrm{Nd}$ isotopes.

[7] Samples were crushed to millimeter-sized chips, ultrasonically cleaned in distilled water and hand-picked under a binocular microscope in order to split the sample into macroscopically homogenous alteration domains, which were then ground to powder in an agate mortar and mill. Glass chips for isotopic analysis were first leached in cold $6 \mathrm{NHCl}$ for 30 minutes to remove possible contamination from handling. Samples were dissolved in hot HF$\mathrm{HNO}_{3}$ and Sr-Nd separated following the column chemistry described by Hoernle and Tilton [1991]. A total of 56 whole rock powders and glass chips were analyzed for ${ }^{87} \mathrm{Sr} /{ }^{86} \mathrm{Sr}$ and ${ }^{143} \mathrm{Nd} /{ }^{144} \mathrm{Nd}$ isotopic compositions by TIMS. On a subset of 43 whole rock powders, $\mathrm{Rb}, \mathrm{Sr}, \mathrm{Sm}$ and $\mathrm{Nd}$ concentrations were determined by ICP-MS.

[8] $\mathrm{Sr}-\mathrm{Nd}$ isotope ratios were analyzed on a Finnigan MAT 262-RPQ ${ }^{2+}$ and TRITON thermal ionization mass spectrometers at IFM-GEOMAR. $\mathrm{Sr}-\mathrm{Nd}$ isotope ratios were measured in static mode except for multidynamic $\mathrm{Nd}$ acquisition on the MAT 262. Sr isotope ratios were normalized within run to ${ }^{86} \mathrm{Sr} /{ }^{88} \mathrm{Sr}=0.1194$ and NBS 987 measured along with the samples gave ${ }^{87} \mathrm{Sr} /{ }^{86} \mathrm{Sr}=$ $0.710221 \pm 0.000021$ ( 2 sigma, $\mathrm{n}=14)$ on the MAT 262 and ${ }^{87} \mathrm{Sr} /{ }^{86} \mathrm{Sr}=0.710252 \pm 0.000006$ ( 2 sigma, $\mathrm{n}=6$ ) on the TRITON. Sr isotopic ratios are reported relative to ${ }^{87} \mathrm{Sr} /{ }^{86} \mathrm{Sr}=0.71025$ for NBS 987. Nd isotope ratios were normalized within run to ${ }^{146} \mathrm{Nd} /{ }^{144} \mathrm{Nd}=0.7219$ and standards gave ${ }^{143} \mathrm{Nd} /{ }^{144} \mathrm{Nd}=0.511712 \pm 0.000012$ ( 2 sigma, $\mathrm{n}=11$ ) for our in-house SPEX $\mathrm{Nd}$ monitor and ${ }^{143} \mathrm{Nd} /{ }^{144} \mathrm{Nd}=0.511843 \pm 0.000009$ ( 2 sigma, $\mathrm{n}=4$ ) for La Jolla on the MAT 262 and ${ }^{143} \mathrm{Nd} /{ }^{144} \mathrm{Nd}=0.511708 \pm 0.000002(2$ sigma, $\mathrm{n}=3$ ) for our in-house SPEX Nd monitor and ${ }^{143} \mathrm{Nd} /{ }^{144} \mathrm{Nd}=0.511844 \pm 0.000007(2$ sigma, $\mathrm{n}=$ 15) for La Jolla on the TRITON.

[9] $\mathrm{Rb}, \mathrm{Sr}, \mathrm{Sm}, \mathrm{Nd}$ concentrations were determined on an Agilent 7500c inductively coupled plasmamass spectrometer (ICP-MS) at the Geological Institute of the University of Kiel using the sample preparation method of Garbe-Schönberg [1993]. Instrument stability was monitored by reanalyzing BHVO-1 every 11 samples resulting in a precision of $<1-2 \%$ RSD for the elements presented here. Relative to working values of Govindaraju [1994] the analytical accuracy for BHVO-1 is within 13\% for $\mathrm{Rb}, 2.6 \%$ for $\mathrm{Sr}, 3 \%$ for $\mathrm{Nd}$ and $5.4 \%$ for $\mathrm{Sm}(\mathrm{n}=$ 4) and within $18.3 \%$ for $\mathrm{Rb}, 3.5 \%$ for $\mathrm{Sr}, 3.7 \%$ for Nd and $2.5 \%$ for Sm for BIR-1 $(n=2)$.

\section{Petrography and Mineralogy}

[10] The basement rocks sampled during Leg 187 comprise mostly aphyric to moderately phyric pillow basalts that either occur as pillow lava or as basaltic rubble. In addition, basaltic breccias were recovered with diverse sedimentary infill: carbonates, clays and lithic debris as cement [Christie et al., 2001]. Plagioclase and olivine are 


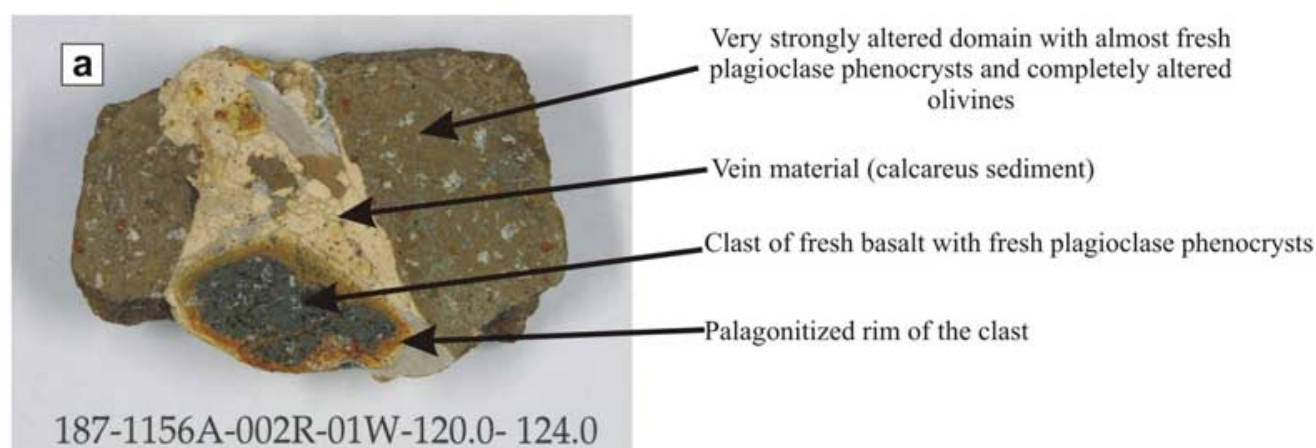

187-1156A-002R-01W-120.0- 124.0


187-1157B-003R-01W-141.0-146.0

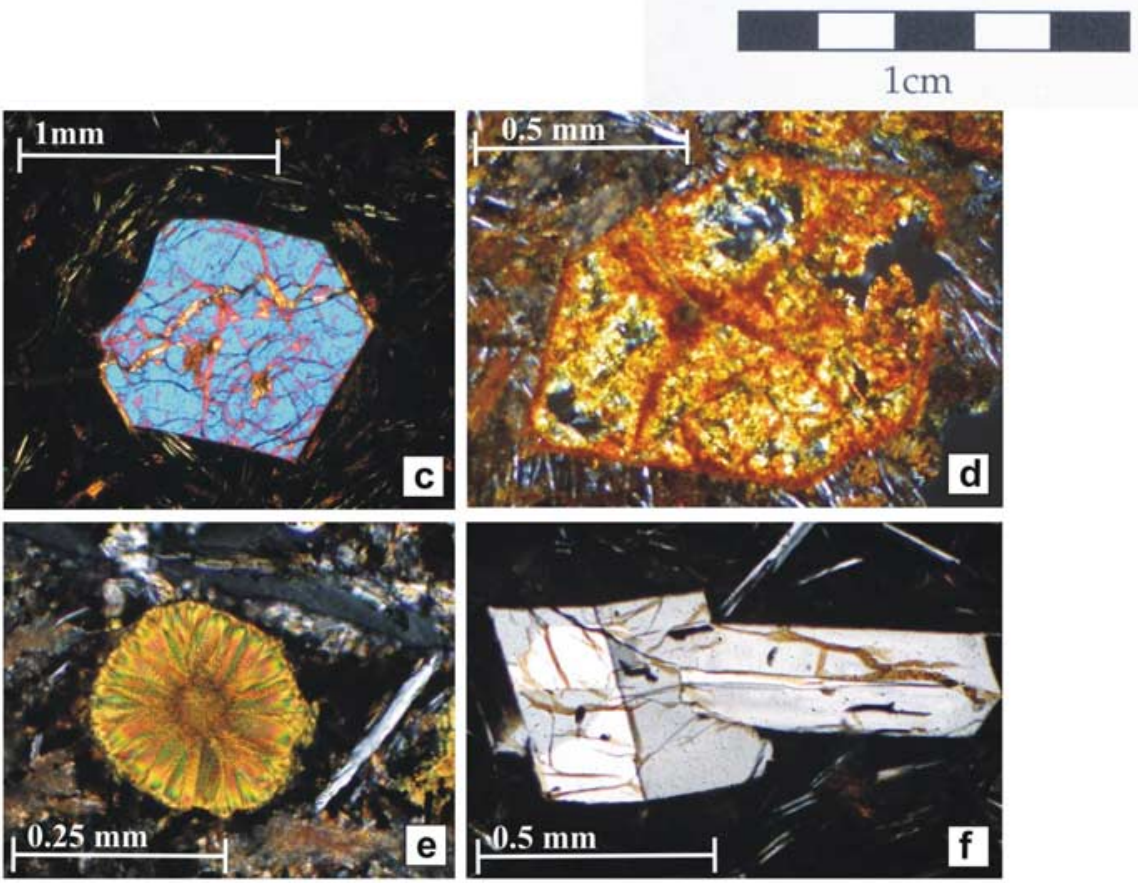

Figure 2. ( $\mathrm{a}$ and $\mathrm{b}$ ) Macroscopically visible types of alteration in two representative samples from ODP Leg 187. (c) Cross-polarized light photomicrograph of fresh olivine from unaltered part of the sample 1157A 3R1 25-27. (d) Cross-polarized light photomicrograph of olivine pseudomorphed by smectites and Fe oxides from a very strongly altered part of sample 1157A 3R1 25-27. (e) Cross-polarized light photomicrograph of olivine pseudomorphed by smectites from weakly altered sample 1154A 5R1 91-93. (f) Cross-polarized light photomicrograph of plagioclase with Fe staining along fractures in medium altered sample 1157B 4R1 136-140. 


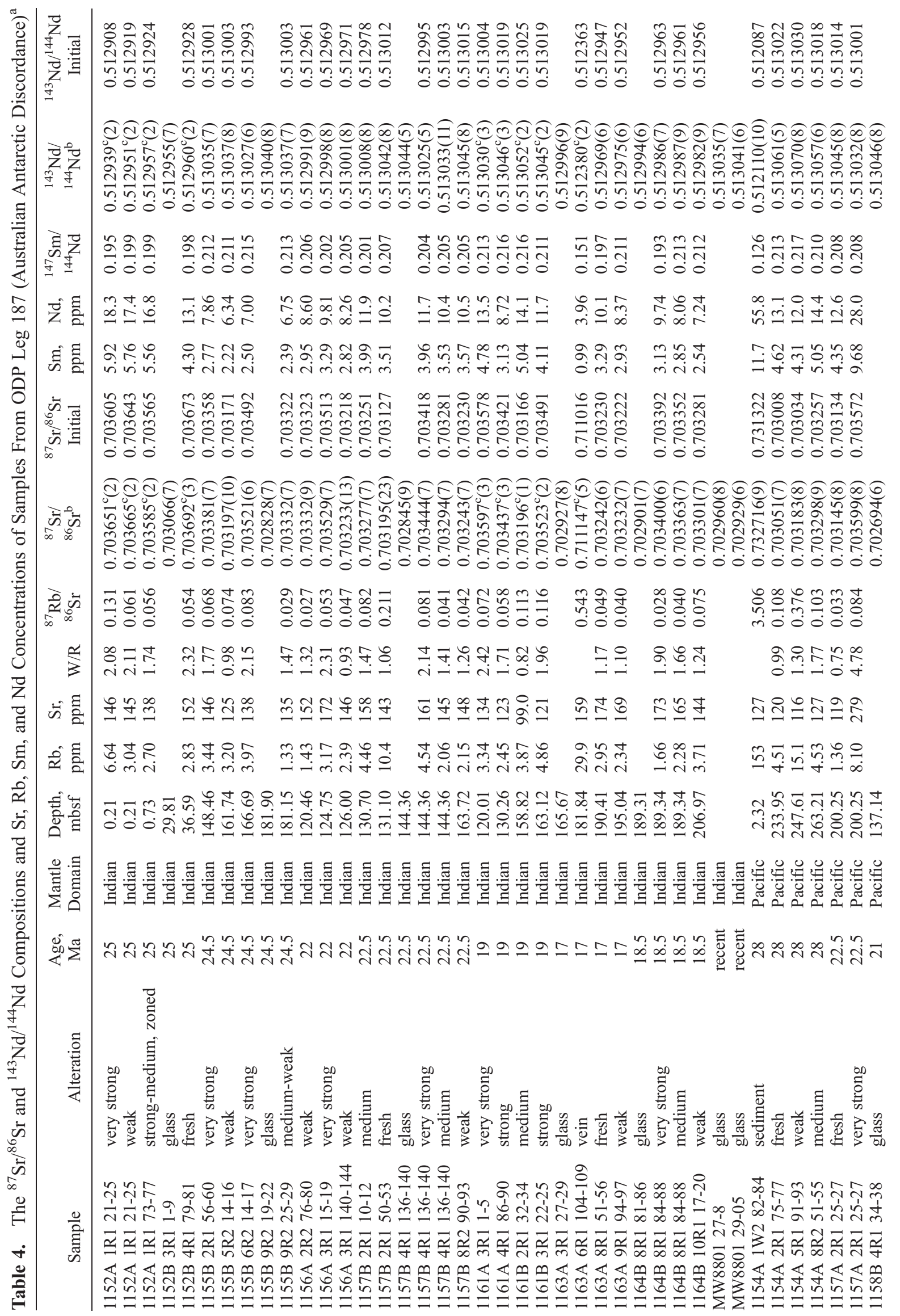




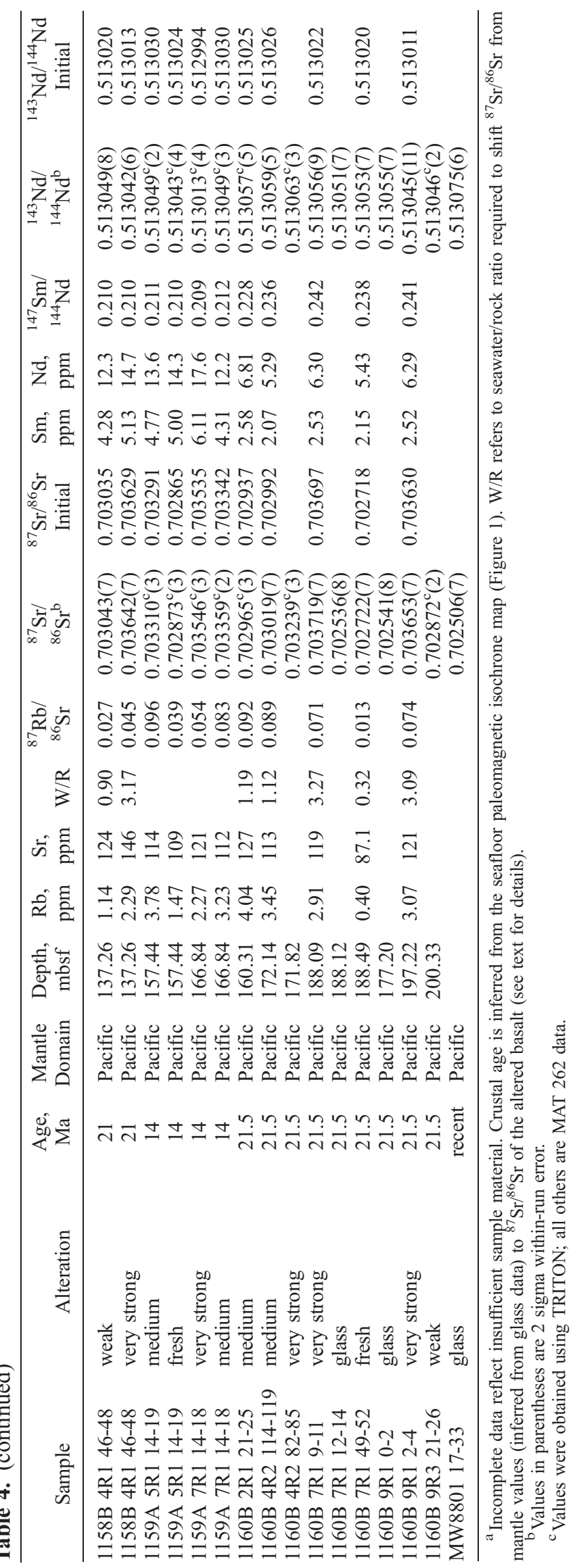


the most common phenocryst phases. Clinopyroxenes were found only in Holes 1152B and 1164A (Figure 1b). Thirty percent of the phenocrysts occur as glomerocrysts, which occur as loose centimeter-sized clusters of prismatic plagioclase and equant olivine or strongly intergrown aggregates. Pillow basalts have microcrystalline groundmass textures, containing plagioclase, olivine and clinopyroxene crystals.

[11] The basalts are altered on a macroscopic scale, recognized as oxidation halos around the margins of samples and along veins and open fractures (Figure 2). On the basis of the type and extent of discoloration, the basalts appear to be variably altered, ranging from virtually pristine (dark gray), through slightly altered (light gray) to completely altered basalts (brown-orange colors). For detailed lithological and petrographic descriptions, see Christie et al. [2001]. Common alteration products are $\mathrm{Fe}$-oxyhydroxides and clay minerals (smectite group), both replacing olivine and clinopyroxene phenocrysts and groundmass, and palagonite replacing glass. Occasionally groundmass is replaced with carbonate which is also a common vein filling. These observations indicate alteration in a low-temperature environment. Celadonite, a very common secondary mineral that is often described in other low-temperature alteration studies [e.g., Marescotti et al., 2000], was not identified in Leg 187 samples by standard petrographic methods applied here. Similarly, characteristic dark black halos described elsewhere [e.g., Talbi and Honnorez, 2003] were also not present in our sample collection. Brief petrographic descriptions of Leg 187 samples used in this study are listed in Table 2. No systematic changes in the macroscopically visible degree of alteration were observed within or between drill sites. Olivine is most susceptible to alteration in all samples; less sensitive is clinopyroxene and plagioclase phenocrysts appear most resistant [Miller and Kelley, 2004]. Plagioclase alteration only occurs as Fe staining along cracks inside crystals (Figure 2f), even in very strongly altered samples with extreme groundmass discoloration to orange-brown. The degree of phenocryst alteration does not always correlate with the degree of groundmass alteration, as partly fresh phenocrysts are sometimes present in strongly altered groundmass.

\section{Analytical Results}

[12] $\mathrm{Sr}$ and $\mathrm{Nd}$ isotopic data and $\mathrm{Sr}, \mathrm{Rb}, \mathrm{Sm}, \mathrm{Nd}$ concentrations are given in Table 4, together with

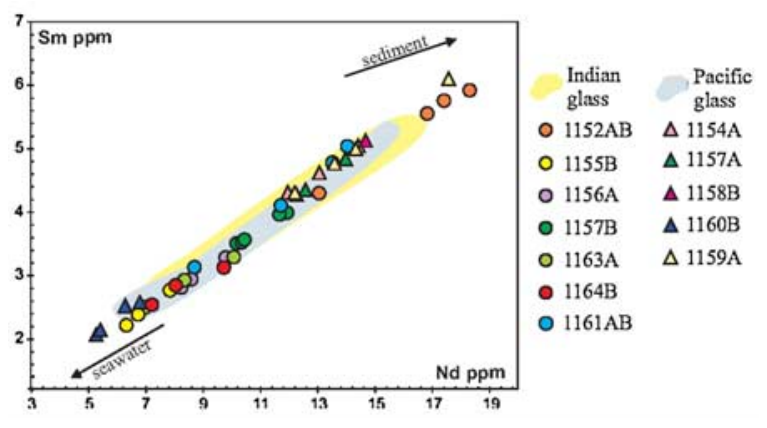

Figure 3. Sm versus $\mathrm{Nd}$ concentrations of 43 variably altered basalt samples from 11 drill sites of ODP Leg 187. The yellow field (Indian mantle domain) and light blue field (Pacific mantle domain) are defined by glass data from the same sites (D. Pyle, personal communication, 2002). In Figures 3-7, circles are used for the Indian mantle domain, and triangles are used for the Pacific mantle domain. Arrows point to the positions of seawater and local sediment that lie outside the plot area.

the macroscopically assigned degree of alteration, age, depth and the calculated seawater/rock ratio of the sample. No correlation exists between any of the studied parameters and borehole depth, most likely reflecting the shallow basement penetration of less than $56 \mathrm{~m}$ in all sites.

\subsection{Sm-Nd and Rb-Sr Concentrations}

[13] In general MORB from the Pacific and Indian mantle domains displays a similar range in Sm and $\mathrm{Nd}$ element concentrations (Figure 3 ) in both glass (2.5-5.4ppm Sm, 6.4-16.5ppm Nd) and whole rock $(2.1-6.1 \mathrm{ppm} \mathrm{Sm}, 5.3-18.3 \mathrm{Nd})$ samples. These concentrations are similar to dredge sample data from this region [Pyle et al., 1995; Klein et al., 1988]. The good covariation of Sm and Nd concentration provides additional evidence that these elements are not affected by alteration. Basalts from the Pacific mantle domain generally extend to lower Sr concentrations (87-146 ppm) than those from the Indian mantle domain (125-174 ppm) (Figure 4), possibly reflecting a primary difference between these mantle domains. Rb concentrations in fresh glass range from 0.05 to $0.92 \mathrm{ppm}$ (Pacific domain) and from 0.47 to $1.47 \mathrm{ppm}$ (Indian domain), whereas $\mathrm{Rb}$ in the altered basalts is significantly higher, ranging from $2 \mathrm{ppm}$ to $15 \mathrm{ppm}$. A correlation between $\mathrm{Sm}, \mathrm{Nd}, \mathrm{Sr}$ and $\mathrm{Rb}$ contents and crustal age is not observed (Figure 5).

\section{2. $\mathrm{Nd}$ and $\mathrm{Sr}$ Isotopes}

[14] The fresh glasses (Figure 6) from the Pacific domain sites have ${ }^{143} \mathrm{Nd} /{ }^{144} \mathrm{Nd}=0.513009$ to 0.513075 . Altered and fresh basalts fall within this 


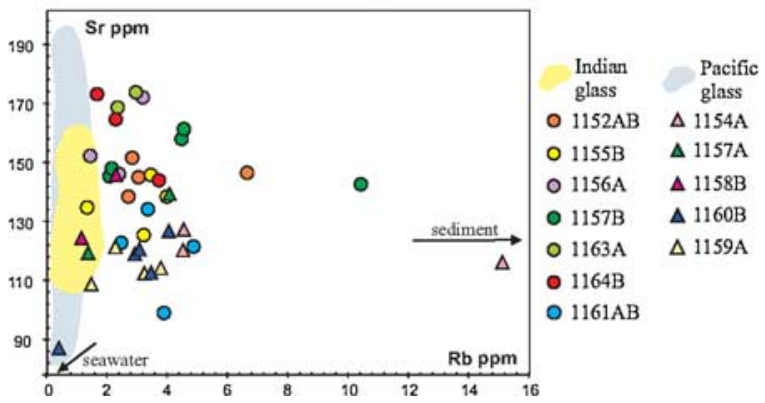

Figure 4. $\mathrm{Rb}$ versus $\mathrm{Sr}$ concentrations of 43 variably altered basalt samples from ODP Leg 187. The yellow field (Indian mantle domain) and light blue field (Pacific mantle domain) are defined by glass data from the same sites (D. Pyle, personal communication, 2002). Arrows point to the positions of seawater and local sediment that lie outside the actual plot area.

range. The fresh Indian-mantle-type glasses display lower overall ${ }^{143} \mathrm{Nd} /{ }^{144} \mathrm{Nd}=0.512921-0.513041$ than the Pacific samples and groundmass of Indian-type basalts largely overlaps the glass data $\left({ }^{143} \mathrm{Nd} /{ }^{144} \mathrm{Nd}=0.512939-0.513052\right)$. Glasses and variously altered basalts from both mantle domains have isotopic ratios that lie within the respective fields of on-axis $\mathrm{AAD}$ lavas [Klein et al., 1988]. Within single sites, ${ }^{143} \mathrm{Nd} /{ }^{144} \mathrm{Nd}$ isotopic ratios remain constant within analytical error and thus show no evidence of basalt seawater exchange (Figure 6). Altered samples show the same range of $\mathrm{Nd}$ contents and ${ }^{143} \mathrm{Nd} /{ }^{144} \mathrm{Nd}$, consistent with the idea that seawater alteration has little effect on $\mathrm{Nd}$. No correlation exists between $\mathrm{Nd}$ concentrations, ${ }^{143} \mathrm{Nd} /{ }^{144} \mathrm{Nd}$ or crustal age (Figure 5).

[15] $\mathrm{The}{ }^{87} \mathrm{Sr} /{ }^{86} \mathrm{Sr}$ ratios (Figure 6) for fresh glasses range from 0.70251 to 0.70270 for the Pacific and ${ }^{87} \mathrm{Sr} /{ }^{86} \mathrm{Sr}=0.70278$ to 0.70308 for the Indianmantle-type basalts. Basalts, even when only slightly altered, have higher ${ }^{87} \mathrm{Sr} /{ }^{86} \mathrm{Sr}$ than the associated glasses. In general the ${ }^{87} \mathrm{Sr} /{ }^{86} \mathrm{Sr}$ appears to become more radiogenic with the macroscopically increasing degree of alteration (Figure 6e) and thus ${ }^{87} \mathrm{Sr} /{ }^{86} \mathrm{Sr}$ may serve as chemical proxy for the degree of seawater alteration at a given ${ }^{143} \mathrm{Nd} /{ }^{144} \mathrm{Nd}$. Exceptions are noted for some macroscopically fresh basalts having similar or even higher $\mathrm{Sr}$ isotopic ratios than very strongly altered samples (e.g., Site 1152) which could reflect that some alteration minerals (e.g., smectites) are not
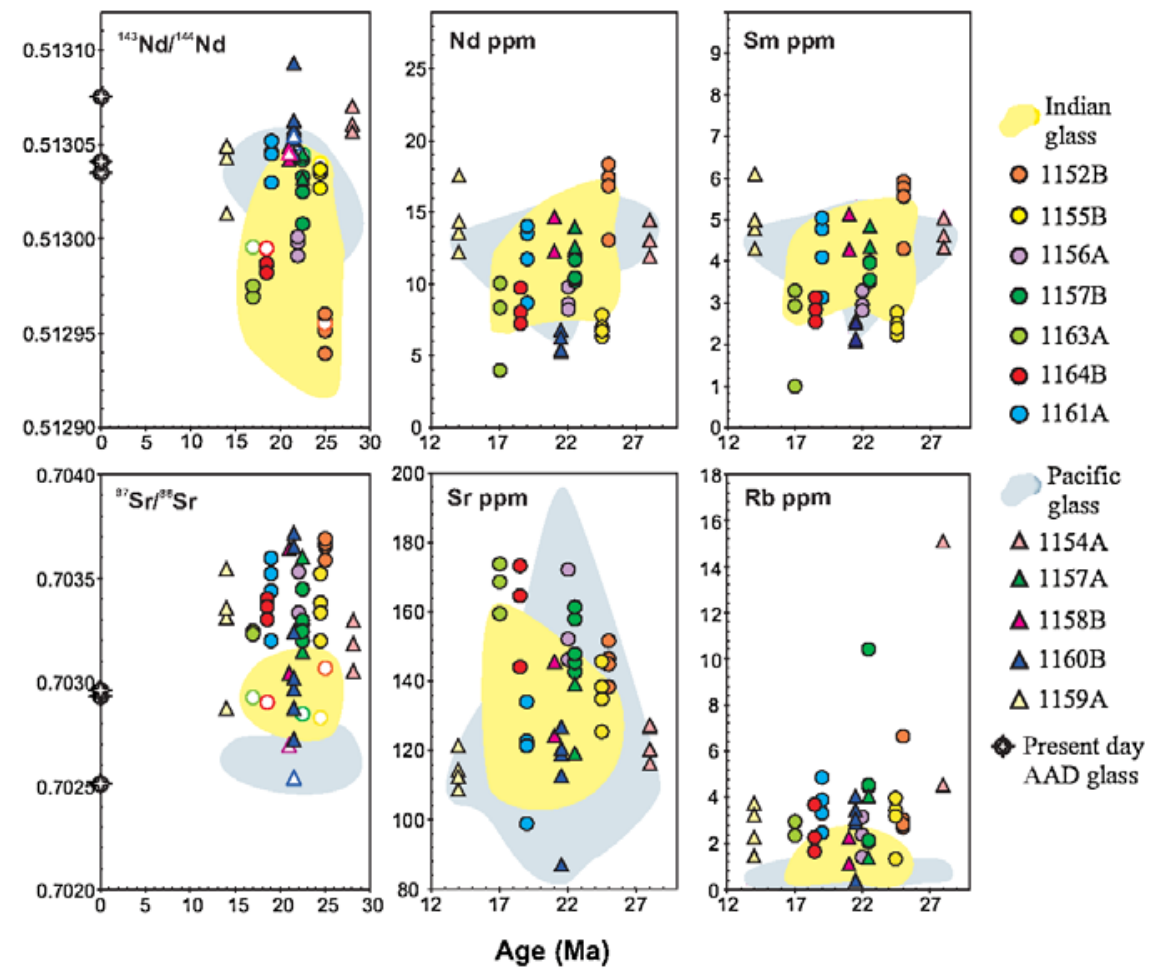

Figure 5. Sr, $\mathrm{Rb}, \mathrm{Nd}$, and Sm concentrations, ${ }^{143} \mathrm{Nd}^{1 / 44} \mathrm{Nd}$ and ${ }^{87} \mathrm{Sr}^{186} \mathrm{Sr}$ of ODP Leg 187 basalts against crustal age. The yellow field (Indian mantle domain) and light blue field (Pacific mantle domain) are defined by glass data from the same sites (D. Pyle, personal communication, 2002). Arrows point to the positions of seawater and local sediment that lie outside the actual plot area. 

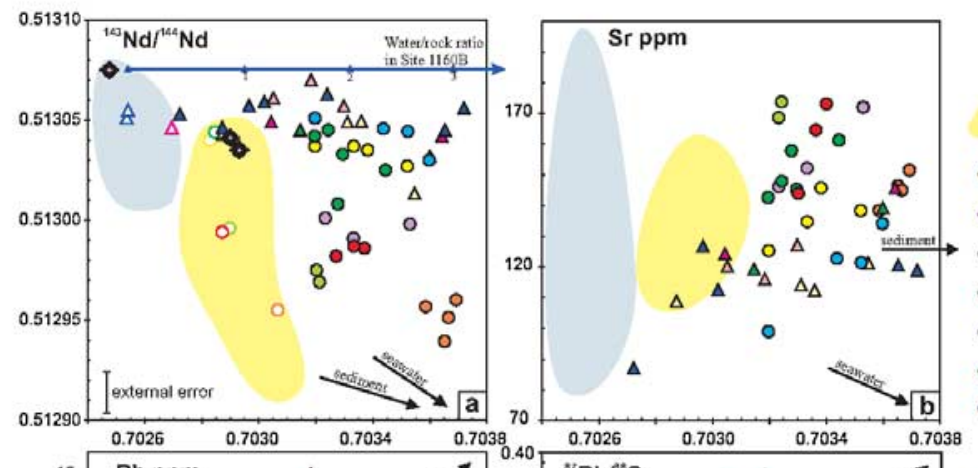

$$
\begin{array}{ll}
\begin{array}{l}
\text { Indian } \\
\text { glass }
\end{array} \\
01152 \mathrm{AB}
\end{array}
$$

○ 1155B

○ 1156A

- 1157B

- $1163 \mathrm{~A}$

- $1164 \mathrm{~B}$

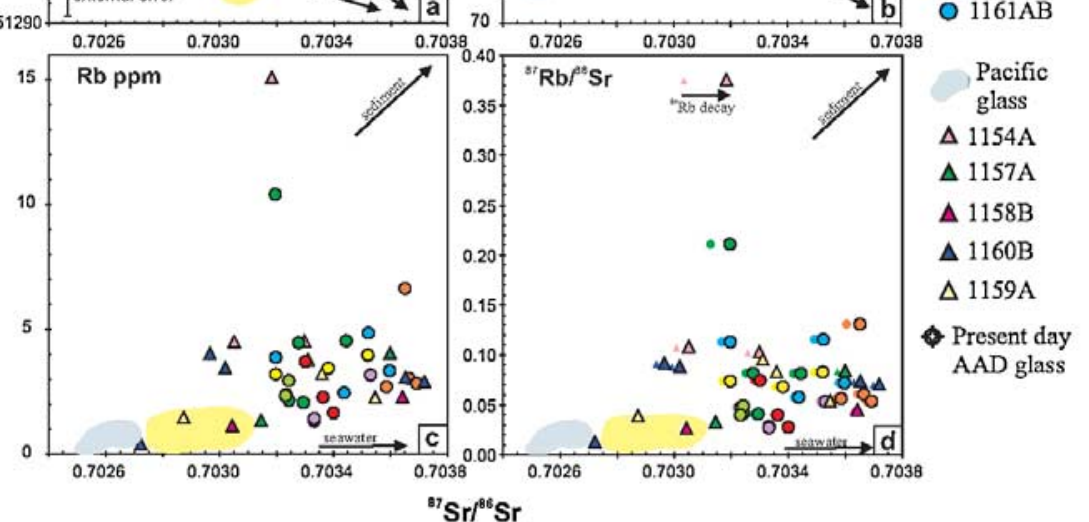

$\mathrm{Sr}{ }^{86} \mathrm{Sr}$

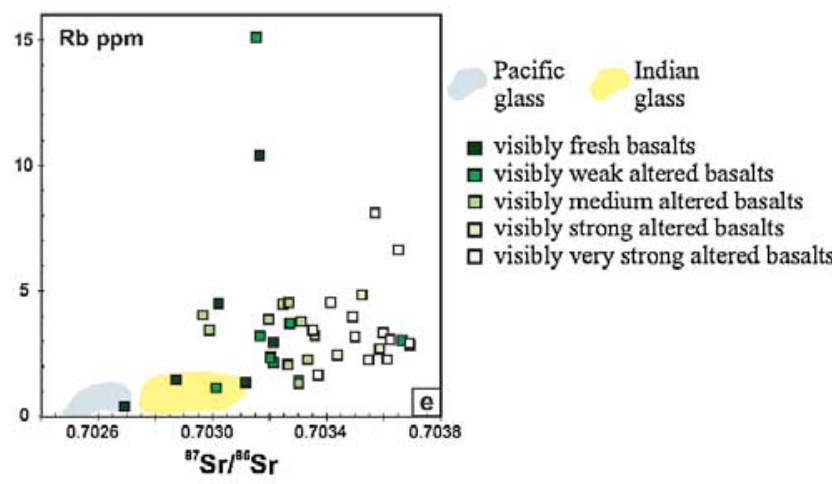

Figure 6. (a) The ${ }^{143} \mathrm{Nd}^{/ 144} \mathrm{Nd}$ versus ${ }^{87} \mathrm{Sr}^{186} \mathrm{Sr}$ isotopic composition of variably altered basalt samples (solid symbols) and fresh glass (open symbols) from ODP Leg 187. Fields are based on glass data from the same sites (D. Pyle, personal communication, 2002). Also shown are modern AAD glasses for reference. Lavas with Indian mantle characteristics seem to extend to less radiogenic ${ }^{143} \mathrm{Nd} /{ }^{144} \mathrm{Nd}$ and more radiogenic ${ }^{87} \mathrm{Sr} /{ }^{86} \mathrm{Sr}$ compositions than those with Pacific mantle characteristics. Within single sites, ${ }^{87} \mathrm{Sr} /{ }^{86} \mathrm{Sr}$ is generally more radiogenic in whole rock than fresh glass, whereas ${ }^{143} \mathrm{Nd} /{ }^{144} \mathrm{Nd}$ is homogenous within analytical error, except at site 1157B. The general offset toward more radiogenic ${ }^{87} \mathrm{Sr} /{ }^{86} \mathrm{Sr}$ in the altered basalts mainly results from addition/exchange of seawater-derived $\mathrm{Sr}$ at hydrated interlayer sites during smectite formation. The arrow points toward increasing seawater/rock ratios required to shift ${ }^{87} \mathrm{Sr} /{ }^{86} \mathrm{Sr}$ from the mantle value of site 1160B (as inferred from site 1160B glass data) to the measured ${ }^{87} \mathrm{Sr} /{ }^{86} \mathrm{Sr}$ of the altered basalts. (b) $\mathrm{Sr}$ concentration versus ${ }^{87} \mathrm{Sr} /{ }^{86} \mathrm{Sr}$. (c) $\mathrm{Rb}$ concentrations versus ${ }^{87} \mathrm{Sr} /{ }^{86} \mathrm{Sr}$. (d) Plot of ${ }^{87} \mathrm{Rb} /{ }^{86} \mathrm{Sr}$ versus ${ }^{87} \mathrm{Sr} /{ }^{86} \mathrm{Sr}$ for measured (black rim) and initial data (no rim). (e) $\mathrm{Rb}$ concentration versus ${ }^{87} \mathrm{Sr} /{ }^{86} \mathrm{Sr}$ with data being sorted by visible degree of alteration. For most samples, no correlation exists between $\mathrm{Rb}$ enrichment and degree of alteration. Two samples which appear fresh to weakly altered display the most extreme $\mathrm{Rb}$ enrichment and have intermediate ${ }^{87} \mathrm{Sr} /{ }^{86} \mathrm{Sr}$ compositions. A general overlap in ${ }^{87} \mathrm{Sr} /{ }^{86} \mathrm{Sr}$ is observed for the fresh through medium altered basalts and the strongly through very strongly altered basalts. Arrows point to the positions of seawater and local sediment that lie outside the actual plot area.

always macroscopically visible. No obvious correlation exists between $\mathrm{Sr}$ concentration and ${ }^{87} \mathrm{Sr} /{ }^{86} \mathrm{Sr}$ ratio or between the ${ }^{87} \mathrm{Sr} /{ }^{86} \mathrm{Sr}$ ratio and the degree of alteration or the age of the crust
(Figure 5). Initial ${ }^{87} \mathrm{Sr} /{ }^{86} \mathrm{Sr}$ ratios, determined using the measured ${ }^{87} \mathrm{Rb} /{ }^{86} \mathrm{Sr}$ ratios, are not significantly shifted from the measured ${ }^{87} \mathrm{Sr} /{ }^{86} \mathrm{Sr}$ values (Figure 6d), indicating that the radiogenic ${ }^{87} \mathrm{Sr} /{ }^{86} \mathrm{Sr}$ 
signature in most samples mainly results from exchange with seawater derived $\mathrm{Sr}$ rather than from

${ }^{87} \mathrm{Rb}$ decay. Exceptions are, however, noted for samples with ${ }^{87} \mathrm{Rb} /{ }^{86} \mathrm{Sr} \geq 0.1$ (Figure $6 \mathrm{~d}$ ).

\section{Discussion}

\subsection{Behavior of the $\mathrm{Rb}-\mathrm{Sr}$ Isotope System During Low-Temperature Alteration}

[16] Present-day seawater has a Sr content of $8 \mathrm{ppm}$ and ${ }^{87} \mathrm{Sr} /{ }^{86} \mathrm{Sr}$ ratio of 0.70906 [Faure, 1986], and therefore can have a strong influence on the $\mathrm{Sr}$ isotopic composition of the oceanic crust. Sr contents of basalts, however, do not appear to increase even in very strongly altered samples (Figure 6b), indicating that $\mathrm{Sr}$ exchange rather than $\mathrm{Sr}$ addition [Kawahata et al., 1987] is the main mechanism for elevating ${ }^{87} \mathrm{Sr} /{ }^{86} \mathrm{Sr}$ in the ocean crust. The most likely explanation for this phenomenon reflects the nature of $\mathrm{Sr}$ absorption into smectites and celadonite, although celadonite was not identified in the studied samples. Both smectite and celadonite are very absorbent minerals and incorporate $\mathrm{Sr}$ most likely into octahedral sites or as hydrated ions into the interlayer sites [Staudigel et al., 1981]. Sr ions have high hydration energy and produce hydrated interlayers and thus remain exchangeable as long as the basaltseawater reaction takes place. This mechanism will increase the ${ }^{87} \mathrm{Sr} /{ }^{86} \mathrm{Sr}$ ratio in the altered basalt due to the exchange with more radiogenic seawater without increasing the total $\mathrm{Sr}$ concentration of the rock.

[17] In contrast, the absorption of Rb into smectites and celadonite is restricted to interlayer sites. $\mathrm{Rb}$ ions have low hydration energy and are preferentially absorbed into interlayer sites where they cause dehydration and successive layer collapse which structurally fixes $\mathrm{Rb}$ [Staudigel et al., 1981]. This mechanism would explain why the concentration of $\mathrm{Rb}$ is higher in altered basalt samples. The highest $\mathrm{Rb}$ concentrations however are observed in two weakly altered samples: (1157B2R150-53 - $10.4 \mathrm{ppm}$ and 1154A5R191$93-15.1 \mathrm{ppm}$ ) where the ${ }^{87} \mathrm{Sr} /{ }^{86} \mathrm{Sr}$ isotopic ratios are relatively low (Figure $6 \mathrm{c}$ ). Therefore in some cases the addition of $\mathrm{Rb}$ into the basalt takes place more rapidly than the ${ }^{87} \mathrm{Sr} /{ }^{86} \mathrm{Sr}$ exchange with seawater. Moreover the amount of $\mathrm{Rb}$ which can be added to smectites is probably unpredictable and not related to the extent of alteration. Otherwise it would be expected that the altered basalts with abundant smectite should have the highest
$\mathrm{Rb}$ contents. Thus even weakly altered basalts with small amounts of secondary smectites are able to take up large amounts of $\mathrm{Rb}$. Macroscopically fresh samples with high $\mathrm{Rb}$ concentrations but "MORB like" ${ }^{87} \mathrm{Sr} /{ }^{86} \mathrm{Sr}$ are also described from Site 843 and by King et al. [1993] and Waggoner [1993] (Figure 7b).

[18] Another mechanism affecting the Rb-Sr system in the ocean crust is the precipitation of carbonates during crustal fracturing which can last up to $100 \mathrm{Ma}$ [Alt and Teagle, 1999]. According to Staudigel et al. [1981], carbonate formation can drastically increase ${ }^{87} \mathrm{Sr} /{ }^{86} \mathrm{Sr}$ and slightly decrease $\mathrm{Rb}$ concentrations but leaves $\mathrm{Sr}$ concentrations in the bulk rock relatively unchanged. Calcite-filled fractures play a minor role in ODP Leg 187 basalts and when present were avoided during sample preparation, since this study primarily investigates the effects of groundmass alteration.

\subsection{Possible Contaminants}

[19] The isotopic composition of the basalts might be influenced by the following contaminants: local sediment, vein material and seawater. Since ${ }^{87} \mathrm{Sr} /{ }^{86} \mathrm{Sr}$ of the local sediment $(0.73272)$ is much more radiogenic than even in the most altered basalt (0.70372), sediment could serve as a possible mixing end-member. In case of bulk assimilation of sediment, it is expected that ${ }^{143} \mathrm{Nd} /{ }^{144} \mathrm{Nd}$ of the altered basalt would also shift from mantle values toward those of the local sediment $\left({ }^{143} \mathrm{Nd} /{ }^{144} \mathrm{Nd}=0.512110\right)$. However, ${ }^{143} \mathrm{Nd} /{ }^{144} \mathrm{Nd}$ ratios of all fresh and altered basalts remain constant within sites suggesting that bulk sediment assimilation does not play a role. In addition, considering the high $\mathrm{Rb}(153 \mathrm{ppm}), \mathrm{Sm}$ (11.7 ppm) and $\mathrm{Nd}(55.8 \mathrm{ppm})$ concentrations in the sediment, bulk assimilation should also have led to a profound increase in the concentration of these elements in the altered basalts, with the greatest increase in $\mathrm{Rb}$ and the lowest increase in Sm. The samples however have on average $3.5 \mathrm{ppm} \mathrm{Rb}, 3.8 \mathrm{ppm} \mathrm{Sm}$ and $11 \mathrm{ppm} \mathrm{Nd}$.

[20] The analyzed vein material (clayey calcarenite) at site $1163 \mathrm{~A}$ comes from a crack within a pillow basalt. Its ${ }^{87} \mathrm{Sr} /{ }^{86} \mathrm{Sr}$ of 0.71115 is more radiogenic than seawater but much less radiogenic than the local sediment. Since the vein material consists of calcarenite and clay, the observed ${ }^{87} \mathrm{Sr} /{ }^{86} \mathrm{Sr}$ most likely represents a mixture of seawater derived calcarenite that precipitated from fluids and detrital clays that accumulated in the crack. The ${ }^{143} \mathrm{Nd} /{ }^{144} \mathrm{Nd}$ composition of the vein 




O ODP 187 Indian sites $14-28 \mathrm{Ma}$
$\mathbf{\Delta}$ ODP 187 Pacific sites $14-28 \mathrm{Ma}$
$\diamond 417 / 418-118 \mathrm{Ma}$ (Staudigel, 1995)

initial $-417 / 418$

\& 504B - $7 \mathrm{Ma}$ (Barret\&Friedrichsen, 1982)

504B - 7 Ma (Kawahats, 1987)

$\diamond 843-110 \mathrm{Ma}$ (Waggoner, 1993)



$1149,801-130-167 \mathrm{Ma}(\mathrm{Hauf}, 2003)$

$\checkmark$ initial 1149,801

$\checkmark$ Gran Canaria - $178 \mathrm{Ma}$ (Hoemle, 1998)

initial Gran Canaria

Figure 7. (a) Comparison of $\mathrm{Sr}$ contents and ${ }^{87} \mathrm{Sr} /{ }^{86} \mathrm{Sr}$ of samples from ODP Leg 187 with literature data of young 7 Ma oceanic crust from Hole 504B (Costa Rica Rift) [Kawahata et al., 1987; Barrett and Friedrichsen, 1982], 110 Ma crust of the Hawaiian Arch, ODP Site 843 [Waggoner, 1993], 118 Ma crust from DSDP/ODP Sites $417 / 418$ (Atlantic crust [Staudigel et al., 1995]), 130-167 Ma basalts from ODP Sites 801 and 1149 (Izu-Bonin-Mariana arc [Hauff et al., 2003; Kelley et al., 2003]), and 178 Ma Jurassic oceanic crust beneath Gran Canaria [Hoernle, 1998]. (b) Comparison of $\mathrm{Rb}$ contents and ${ }^{87} \mathrm{Sr} /{ }^{86} \mathrm{Sr}$ of samples from ODP Leg 187 with literature data (data sources are the same as in Figure 7a). Literature data are normalized to ${ }^{87} \mathrm{Sr} /{ }^{86} \mathrm{Sr}=0.71025$ for NBS 987.

$(0.512380)$ is higher than seawater $(0.512228$ [Frank et al., 2002]) and sediment $\left({ }^{143} \mathrm{Nd} /{ }^{144} \mathrm{Nd}=\right.$ 0.512110 ), suggesting the involvement of radiogenic $\mathrm{Nd}$ from basalt in the formation of the vein material. The vein material has low Sm (1 ppm) and $\mathrm{Nd}(4 \mathrm{ppm})$ concentrations which are lower than in the basalts and significantly lower than in the sediment reflecting the precipitation of the calcarenite from fluids with low REE contents. The high $\mathrm{Rb}$ concentration (30 ppm), however, most likely comes from clayey particles deposited in the crack.

[21] In summary, seawater has high $\mathrm{Sr}$ concentration $(8 \mathrm{ppm})$ and radiogenic ${ }^{87} \mathrm{Sr} /{ }^{86} \mathrm{Sr}(0.70906)$ which can be exchanged with the unradiogenic ${ }^{87} \mathrm{Sr} /{ }^{86} \mathrm{Sr}$ of the basalts. The $\mathrm{Rb}$ concentration in seawater is low $(0.11 \mathrm{ppm})$ but $\mathrm{Rb}$ can be increased in basalts through smectite formation. On the other hand, Sm and Nd are fluid immobile elements and their concentrations in seawater $\left(\mathrm{Nd}=2.6 \times 10^{-6} \mathrm{ppm}\right.$ and $\mathrm{Sm}=0.545 \times$ $\left.10^{-6} \mathrm{ppm}\right)$ are too low to influence the compositions of basalts. Although the long-lasting reaction between seawater and basalt can considerably influence the $\mathrm{Nd}$ isotopic composition of seawater [Staudigel et al., 1995], the water/basalt ratio must exceed $10^{5}$ to change $\mathrm{Nd}$ isotopic ratios of basalt significantly [Faure, 1986]. Consequently, the most probable contaminant for the basalts is seawater. A mixing calculation between seawater and pristine glass shows that the maximum seawater/rock ratio is up to 3 in order to shift the ${ }^{87} \mathrm{Sr} /{ }^{86} \mathrm{Sr}$ from the local mantle value toward the 
most radiogenic ${ }^{87} \mathrm{Sr} /{ }^{86} \mathrm{Sr}$ of the altered basalt (Figure 6a).

\subsection{Comparison With Literature Data of Altered Crust}

[22] Figure 7 shows a comparison of our $\mathrm{Sr}$ isotope data with literature data of altered oceanic crust of different ages from other DSDP/ODP sites. Despite the huge age difference ( 7 to $167 \mathrm{Ma}$ ) most studies show, similar to our study, increased ${ }^{87} \mathrm{Sr} /{ }^{86} \mathrm{Sr}$ ratios, increased $\mathrm{Rb}$ concentrations and unchanged Sr contents with no intercorrelation of these parameters. An exception is observed for artificial composites from Site 417/418 with much more radiogenic ${ }^{87} \mathrm{Sr} /{ }^{86} \mathrm{Sr}$, and much higher $\mathrm{Rb}$ concentrations. The most reasonable explanation is that interpillow hyaloclastites, which have very radiogenic ${ }^{87} \mathrm{Sr} /{ }^{86} \mathrm{Sr}$ ratios (e.g., 0.709893) and high $\mathrm{Rb}$ abundances [Hauff et al., 2003], were integrated into the composites, pointing out one of the problems in using composite samples.

[23] Basalt-seawater interaction is thought to take place as long as the oceanic crust is permeable. The permeability of the oceanic crust correlates with age and decreases exponentially from $1 \mathrm{Ma}$ to $8 \mathrm{Ma}$ [Fisher and Becker, 2000]. The extent of lowtemperature alteration is controlled by the type of extrusive material and crustal age [Jarrard, 2003] but is probably restricted to the first few million years after eruption of the basalt and finishes when the crust is "corked up" by secondary minerals and overlaying sediment [Talbi and Honnorez, 2003]. Jarrard [2003] in a numerical model based on matrix densities and potassium contents of smectite, celadonite and fresh basalt, identified that macroporosity and intergranular alteration to smectite, celadonite, and calcite wanes with increasing age. Our ${ }^{87} \mathrm{Sr} /{ }^{86} \mathrm{Sr}$ data show that the degree of low-temperature alteration in Leg 187 basalts is pervasive, unsystematically distributed and independent of age.

[24] Newly generated oceanic crust is subject to seawater alteration in the vicinity of spreading axes. The longevity of ocean crust alteration depends on the initial permeability of the crust, basement tectonics, spreading rate, sedimentation rate and heat flow, which control the access and circulation of seawater in the crust. When the permeability of the uppermost basaltic crust becomes too low, seawater circulation will cease. Thereafter this altered but impermeable section of the ocean crust will evolve as a closed system with radioactive decay being the only process changing the isotopic composition of this crust. This system can, however, be reopened through tectonic and thermal processes in conjunction with subduction or intraplate volcanism.

\section{Conclusions}

[25] In the uppermost magmatic portion of ocean crust drilled during ODP Leg 187, no clear correlation exists between various alteration parameters and crustal age in either Pacific- or Indian-type crust, suggesting that the extent of alteration in 14-28 Ma ocean crust is not a function of time. The primary composition of basalts doesn't have any influence on the alteration process, since samples from both mantle domains are altered similarly. The $\mathrm{Rb}-\mathrm{Sr}$ isotope system appears to be most efficiently altered through exchange with seawater derived $\mathrm{Sr}$ and addition of $\mathrm{Rb}$ within the first few million years after formation of the ocean crust. Within several million years of formation, the permeability in most oceanic crust will approach zero, thus effectively closing the system to further low-temperature alteration.

[26] In order to estimate the amount of seawater necessary to change ${ }^{87} \mathrm{Sr} /{ }^{86} \mathrm{Sr}$ from pristine magmatic compositions toward seawater compositions, a water/rock ratio was calculated after Faure [1986]:

$$
\frac{W}{R}=\left(\frac{\varepsilon_{r}^{i}-\varepsilon_{r}^{f}}{\varepsilon_{r}^{f}-\varepsilon_{w}^{i}}\right)\left(\frac{X_{r}}{X_{w}}\right)
$$

where $\varepsilon$ is the isotope ratio of element $X$ and $W$ and $R$ are the weights of seawater and rock. $X_{r}$ and $X_{w}$ are the concentrations of element $X$ in rock $(r)$ and water $(w)$ respectively, and the superscripts $i$ and $f$ identify the initial $(i)$ and final $(f)$ values of the epsilon parameters.

\section{Acknowledgments}

[27] We thank William M. White (editor), Catherine Chauvel (associate editor), Katherine A. Kelley (reviewer) and an anonymous reviewer for their constructive and positive comments that improved the initial version of this paper. We are grateful to D. Garbe-Schönberg for carrying out trace elements analyses. This study was funded by the Deutsche Forschungsgemeinschaft (grants HA 3097/1-1, 2) and supported by a Ph.D. fellowship grant to Sylwia Krolikowska-Ciaglo by Friedrich-Naumann-Stiftung (resources from German Federal Ministry of Education and Research (BMBF)). This research used samples and/or data provided by the Ocean Drilling Program (ODP). ODP is sponsored by the U.S. National 
Science Foundation (NSF) and participating countries under management of Joint Oceanographic Institutions (JOI), Inc.

\section{References}

Alt, J. C., and D. A. H. Teagle (1999), The uptake of carbon during alteration of ocean crust, Geochim. Cosmochim. Acta, 63(10), 1527-1535.

Alt, J. C., D. A. H. Teagle, W. Bach, A. N. Halliday, and J. Erzinger (1996a), Stable and strontium isotopic profiles through hydrothermally altered upper oceanic crust, Hole 504 B, Proc. Ocean Drill. Program Sci. Results, 148, 57-69.

Alt, J. C., et al. (1996b), Hydrothermal alteration of a section of upper oceanic crust in the eastern equatorial Pacific: A synthesis of results from Site 504 (DSDP Legs 69, 70, and 83, and ODP Legs 111, 137, 140, and 148), Proc. Ocean Drill. Program Sci. Results, 148, 417-434.

Bach, W., J. C. Alt, Y. Niu, S. E. Humphris, J. Erzinger, and H. J. B. Dick (2001), The geochemical consequences of latestage low-grade alteration of lower ocean crust at the SW Indian Ridge: Results from ODP Hole 735 (Leg 176), Geochim. Cosmochim. Acta, 65, 3267-3287.

Bach, W., B. Peucker-Ehrenbrick, S. R. Hart, and J. S. Blusztajn (2003), Geochemistry of hydrothermally altered oceanic crust: DSDP/ODP Hole 504B-Implications for seawatercrust exchange and $\mathrm{Sr}$ - and $\mathrm{Pb}$-isotopic evolution of the mantle, Geochem. Geophys. Geosyst., 4(3), 8904, doi:10.1029/ $2002 \mathrm{GC} 000419$.

Barrett, T. J., and H. Friedrichsen (1982), Strontium and oxygen isotopic composition of some basalts from Hole 504B, Costa Rica Rift, DSDP Legs 69 and 70, Earth Planet. Sci. Lett., 60, 27-38.

Christie, D. M., B. P. West, D. G. Pyle, and B. B. Hanan (1998), Chaotic topography, mantle flow and mantle migration in the Australian-Antarctic discordance, Nature, 394, 637-644.

Christie, D. M., et al. (2001), Proceedings of the Ocean Drilling Program, Initial Reports [Online], vol. 187, Ocean Drill. Program, College Station, Tex. (Available at http://wwwodp.tamu.edu/publications/187_IR/187ir.htm)

Faure, G. (1986), Principles of Isotope Geology, John Wiley, Hoboken, N. J.

Fisher, A. T., and K. Becker (2000), Channelized fluid flow in oceanic crust reconciles heat flow and permeability data, Nature, 403, 71-74.

Forsyth, D. W., R. L. Ehrenbard, and S. Chapin (1987), Anomalous upper mantle beneath the Australian-Antarctic discordance, Earth Planet. Sci. Lett., 84, 471-478.

Frank, M., N. Whiteley, S. Kasten, J. R. Hein, and K. O'Nions (2002), North Atlantic Deep Water export to the Southern Ocean over the past 14 Myr: Evidence from $\mathrm{Nd}$ and $\mathrm{Pb}$ isotopes in ferromanganese crusts, Paleoceanography, 17(2), 1022, doi:10.1029/2000PA000606.

Garbe-Schönberg, C.-D. (1993), Simultaneous determination of thirty-seven trace elements in twenty-eight international rock standards by ICP-MS, Geostand. Newsl., 17, 81-97.

Govindaraju, K. (1994), Compilation of working values and sample description for 383 geostandards, Geostand. Newsl., $18,1-158$.

Hauff, F., K. Hoernle, and A. Schmidt (2003), Sr-Nd-Pb composition of Mesozoic Pacific oceanic crust (Site 1149 and 801, ODP Leg 185): Implications for alteration of ocean crust and the input into the Izu-Bonin-Mariana subduction system, Geochem. Geophys. Geosyst., 4(8), 8913, doi:10.1029/2002GC000421.
Hoernle, K. (1998), Geochemistry of Jurassic oceanic crust beneath Gran Canaria (Canary Islands): Implications for crustal recycling and assimilation, J. Petrol., 39(5), 859-880.

Hoernle, K. A., and G. R. Tilton (1991), Sr-Nd-Pb isotope data for Fuerteventura (Canary Islands) basal complex and subaerial volcanics:applications to magma genesis and evolution, Schweiz. Mineral. Petrogr. Mitt., 71, 3-18.

Jarrard, R. D. (2003), Subduction fluxes of water, carbon dioxide, chlorine, and potassium, Geochem. Geophys. Geosyst., 4(5), 8905, doi:10.1029/2002GC000392.

Johnson, H. P., and S. W. Semyan (1994), Age variations in the physical properties of oceanic basalts: Implications for crustal formation and evolution, J. Geophys. Res., 99, 3123-3134.

Kawahata, H., M. Kusakabe, and Y. Kikuchi (1987), Strontium, oxygen, and hydrogen isotope geochemistry of hydrothermally altered and weathered rocks in DSDP Hole 504B, Costa Rica Rift, Earth Planet. Sci. Lett., 85, 343-355.

Kelley, K. A., T. Plank, J. Ludden, and H. Staudigel (2003), Composition of altered oceanic crust at ODP Sites 801 and 1149, Geochem. Geophys. Geosyst., 4(6), 8910, doi:10.1029/ 2002GC000435.

Kempton, P. D., J. A. Pearce, T. L. Barry, J. G. Fitton, C. Langmuir, and D. M. Christie (2002), Sr-Nd-Pb-Hf isotope results from ODP Leg 187: Evidence for mantle dynamics of the Australian-Antarctic Discordance and origin of the Indian MORB source, Geochem. Geophys. Geosyst., 3(12), 1074, doi:10.1029/2002GC000320.

King, A. J., D. G. Waggoner, and M. O. Garcia (1993), Geochemistry and petrology of basalts from Leg 136, central Pacific Ocean, Proc. Ocean Drill. Program Sci. Results, 136, 107-118.

Klein, E. M., C. H. Langmuir, A. Zindler, H. Staudigel, and B. Hamelin (1988), Isotope evidence of mantle convection boundary at the Australian-Antarctic Discordance, Nature, $333,623-629$.

Marescotti, P., D. A. Vanko, and R. Cabella (2000), From oxidazing to reducing alteration: Mineralogical variations in pillow basalts from the east flank, Juan de Fuca Ridge, Proc. Ocean Drill. Program Sci. Results, 168, 119-136.

Marks, K. M., P. R. Vogt, and S. A. Hall (1990), Residual depth anomalies and the origin of the Australian-Antarctic Discordance Zone, J. Geophys. Res., 95, 17,325-17,337.

Miller, D. J., and J. Kelley (2004), Low-temperature alteration of basalt over time: A synthesis of results from Ocean Drilling Program Leg 187, Proc. Ocean Drill. Program Sci. Results [Online], 187. (Available at http://www-odp.tamu. edu/publications/187 SR/206/206.htm)

Pedersen, R. B., D. M. Christie, and D. G. Pyle (2004), Regional and local mantle heterogeneities associated with the Australian Antarctic Discordance: $\mathrm{Sr}$ and Nd isotopic results from ODP Leg 187, Proc. Ocean Drill. Program Sci. Results [Online], 187. (Available at http://wwwodp.tamu.edu/publications/187_SR/VOLUME/205/ 205.htm).

Pyle, D. G., D. M. Christie, and J. J. Mahoney (1992), Resolving an isotopic boundary within the Australian-Antarctic Discordance, Earth Planet. Sci. Lett., 112, 161-178.

Pyle, D. G., D. M. Christie, J. J. Mahoney, and R. A. Duncan (1995), Geochemistry and geochronology of ancient southwest Indian and southwest Pacific seafloor, J. Geophys. Res., $100,22,261-22,282$.

Schmincke, H.-U., A. Klügel, T. H. Hansteen, K. Hoernle, and P. Bogaard (1998), Samples from the Jurassic ocean crust beneath Gran Canaria, La Palma and Lanzarote (Canary Islands), Earth Planet. Sci. Lett., 163, 343-360. 
Staudigel, H., S. R. Hart, and S. H. Richardson (1981), Alteration of the oceanic crust: Processes and timing, Earth Planet. Sci. Lett., 52, 311-327.

Staudigel, H., G. R. Davies, R. H. Stanley, K. M. Marchant, and B. M. Smith (1995), Large scale isotopic Sr, Nd and $\mathrm{O}$ isotopic anatomy of altered oceanic crust: DSDP/ODP sites 417/418, Earth Planet. Sci. Lett., 130, 169-185.

Staudigel, H., T. Plank, B. White, and H. U. Schmincke (1996), Geochemical fluxes during seafloor alteration of the basaltic upper oceanic crust: DSDP Sites 417 and 418, in Subduction: Top to Bottom, Geophys. Monogr. Ser, vol. 96, pp. 19-38, edited by G. E. Bebout et al., AGU, Washington, D. C.
Talbi, E. H., and J. Honnorez (2003), Low-temperature alteration of mesozoic oceanic crust, Ocean Drilling Program Leg 185, Geochem. Geophys. Geosyst., 4(5), 8906, doi:10.1029/ 2002 GC000405.

Waggoner, D. G. (1993), The age and alteration of central Pacific Oceanic crust near Hawaii, Site 843, Proc. Ocean Drill. Program Sci. Results, 136, 119-132.

Zhou, W., R. Van der Voo, D. R. Peacor, D. Wang, and Y. Zhang (2001), Low-temperature oxidation in MORB of titanomagnetite to titanomaghemite: A gradual process with implications for marine magnetic anomaly amplitudes, J. Geophys. Res., 106, 6409-6421. 